\title{
NEWS VALUES AND THE INFORMATION SOURCE: THE DISCOURSE OF ELITENESS AND PERSONALISATION IN THE DIGITAL PRESS
}

\section{OS VALORES DAS NOTÍCIAS E A FONTE DE INFORMAÇÃO: O DISCURSO DA ELITE E A PERSONALIZAÇÃO NA IMPRENSA DIGITAL}

\author{
Lidia Mañoso-Pacheco \\ Universidade de Nebrija, Espanha \\ Imanoso@nebrija.es
}

\begin{abstract}
This paper proposes a corpus-based examination of the discourse of eliteness and personalisation news values in the information source. To that end, the study compares digital news in British and Spanish corpora. The results reveal a tendency to quote elites, which are frequently constructed by means of recognised names from politics, inanimate references with broad scope and role labels in apposition. To a lesser extent, prestige is construed through status-indicating modifiers and allusion to place of work. Ordinary sources, however, are usually construed via indication of provenance, reference to family relationship and anaphoric allusions, mostly in British sources. It remains to be clarified whether the construal of these values is in consonance with the editorial stance of the newspaper.
\end{abstract}

KEYWORDS: discourse; eliteness; information source; news values; personalisation.

RESUMO: Este artigo propõe um exame, baseado em corpus, do discurso da elite e a personalização dos valores informacionais na fonte de informação. Para isso, o estudo compara as notícias digitais em corpora britânicos e espanhóis. Os resultados revelam uma tendência a citar as elites, que são frequentemente construídas através de nomes políticos reconhecidos, referências inanimadas de grande alcance e etiquetas de papel na aposição. Em menor medida, o prestígio é interpretado através de modificadores que indicam status e alusões ao lugar de trabalho. As fontes comuns, no entanto, são geralmente interpretadas através da indicação de proveniência, referência à relação familiar e alusões anafóricas, especialmente em fontes britânicas. Resta esclarecer se a interpretação destes valores está em consonância com a postura editorial do jornal.

PALAVRAS-CHAVE: discurso; elitismo; fonte de informação; valores informacionais; personalização.

\section{Introduction}

Newsgathering has traditionally been claimed to be more of an art than a science. The selection of news content that may satisfy the audience corresponds to the instincts of news editors, who are said to need a 'nose' for predicting the newsworthy value of a piece of news (BOYD, 2001; SERGEANT, 2001). However, having the individual ability to predict newsworthiness is not sufficient to produce news items, the selection is rather exercised within the constraints of the media outlets within which journalists operate (HARRISON, 


\section{6, p. 13).}

News reporters do not just act as gatekeepers, i.e. decision-makers accountable for the selection of events from the array of information available, they also have to cope with the market. Although the media institutions are expected to meet the needs of society, editorial priorities usually comply with commercial purposes (ALLERN, 2011; CAPLE, 2018). Thus, journalists in the newsroom do not just consider "the fresh, unpublished, unusual and generally interesting" (RANDALL, 2000, p. 23) when selecting information for publication, they also aim to conform to the prevailing economic norms.

Reporters, in particular those publishing online, must also be able to address time constraints. According to De Nies et al., "the consumer needs for near-immediate reporting significantly limits the time for journalists to select and produce content", which together with the vast amount of information readers have at their quick disposal, hamper the management of an event in terms of its alleged newsworthiness (2012, p. 106).

Framing news stories as interestingly as possible also belongs to media reporters (GUO, 2012, p. 27). The portrayal of an event necessarily involves that some details surrounding it must be disregarded. This fact could be detrimental to readers, as they have little control over the details that have not been included, nor do they have access to the original source of information to assess the validity of the report (REAH, 2001, p. 5). As a matter of fact, "people who have been involved in newsworthy events that have been ignored or misrepresented by the newspapers often find themselves wondering what else may be excluded from coverage, or presented in a misleading way" (2001, p. 5). Nevertheless, the exclusion of elements does not always imply negative intent, on many occasions newspapers focus on certain aspects of an event without any ulterior motive (STAAB, 1990, p. 439).

On the basis of the assumption that subjectivity is innate in language and that a certain bias is always going to be present in journalistic discourse, both in news selection and construction (FOWLER, 1994; BLANCO-GÓMEZ, 2004), the present paper analyses eliteness and personalisation news values, with an emphasis on the way they are constructed in the discourse. In order to assess newsworthiness in digital storytelling, an in-depth study of information sources is carried out. The corpus-based study analyses digital news published in British and Spanish quality papers and is organised as follows: section 2 discusses literature on the conceptualisation of newsworthiness by focusing on Bednarek and Caple's approach (2017). Section 3 continues analysing reported speech and the construction of news values, in particular eliteness and personalisation. Section 4 explains and justifies the methodology employed in the corpora. Both quantitative and qualitative results are presented in section 5. Finally, section 6 is devoted to the conclusions and suggests some lines for further research in the field. Due to the relatively small size of information sources analysed, the value of the results is limited with regard to these news judgements, though the researcher launches some preliminary findings in the paper as a prelude to having more consistent results.

\section{Conceptual distinctions}

News values, or the set of factors that confers newsworthiness to the stories, have been one of the key areas of enquiry in critical discourse analysis and media linguistics. In 
journalism-related research, they are said to play a core role in the news process. As Shoemaker (2006) indicates, newsworthiness is a cognitive construct or mental judgement that comprises a wide range of factors that influence what becomes news, as well as the prominence of the events covered. It thus appears indisputable that news values "drive the way news stories are gathered, structured and presented", having great influence over the selection and presentation of news events and thus constituting one of the primary functions of copy editors (BELL, 2001, p. 76, 247).

However, there has been wide debate regarding their definition and measurement, resulting in the treatment of the term 'news values' as a misleading concept (O'NEILL; HARCUP, 2009; BEDNAREK, 2016). News values can be approached through different perspectives, but even under the same scope, research studies do not assess these qualities in an equal way, nor do they use the same terminology to refer to them. According to Bednarek and Caple, news values can be defined from four distinct dimensions, as follows:

An event and its material reality holds potential news value for a given community (material); that news workers and audience members have beliefs about news values and newsworthiness (cognitive); that news values are applied as selection criteria in journalistic practice (social), and that news values can be communicated through discourse (discursive) (2017, p. 42).

The material perspective presupposes news values as intrinsic to news events since it alludes to the 'potentiality' of newsworthy factors. This approach has been recently criticised, as the news values that are constructed in a text do not need to be intrinsic to the corresponding news event (BEDNAREK; CAPLE, 2017).

In the case of the cognitive dimension, it refers to the news qualities that reporters and/or the audience confer on a story, which may, in turn, determine the selection and subsequent publication of the event (social dimension). The cognitive stage is often exerted unconsciously by newsworkers and comprises predicting decisions about the supposed preferences of the target audience (BELL, 2001, p. 155; RICHARDSON, 2007, p. 94). According to Van Dijk, the mere term 'value' implies the placement of news values in social cognition, and so these properties appear to set the cognitive basis concerning the selection, focus, processing and representation of news items (1988, p. 119). Following the cognitive view, news reporters select an event depending on their judgements upon its inherent newsworthy value(s) and consequently, "the more of these news values are satisfied, the more likely an event will be selected" (DE NIES et al., 2012, p. 107). Nevertheless, the cognitive dimension frequently conflates with the other aspects (material, social and discourse), and so a more comprehensive position is needed to assess the intricacy of newsworthiness.

Finally, the discursive perspective entails the way news values are constructed through discourse, the target of the present investigation. Once an event has been chosen to be reported in the press, it needs to be moulded in as newsworthy a way as possible. The devices used to construct newsworthiness are usually conventionalised as a consequence of the journalistic practice carried out through time, some of them being labelled as 'journalistic clichés' (LOZADA, 2014; BEDNAREK; CAPLE, 2017).

Concerning the written press, the discursive stage is articulated through the 
dimension of space, i.e. the general layout of the newspaper article, together with the linguistic units that configure the news events (COTTER, 2010, p. 75). The visual component may be noticeable in both print media and online newspapers, though visuals are more important in the online environment. Online newspapers frequently 'play' with space in that they organise their home page and the news articles within the journal depending on the presence (or absence) of news values. However, the study of visuals goes beyond the present study.

Apart from the above-explained dimensions through which news values can be approached, there are many other factors that may influence the selection of events as news, such as deadlines, commercial imperatives, economic constraints, and cultural and political considerations (O'NEILL; HARCUP, 2009; BEDNAREK; CAPLE, 2017). These factors are context-sensitive, as they can change over time and be affected by the place of publication, not to mention the influence exerted by the audience and the newspaper's policy (O'NEILL; HARCUP, 2009; BEDNAREK; CAPLE, 2017). However, in most scholarly publications these aspects are not considered, defined or labelled as news values (BEDNAREK; CAPLE, 2017).

In conclusion, news values, or the set of categories that confers newsworthiness to news stories, do not only have a gatekeeping role in the selection of events, but they also incarnate wide-ranging factors that affect the newsworthy quality of the information. Consequently, following an interdisciplinary approach is always at play when approaching these values.

\section{News values and the information source}

Walter Lippmann (1922) was the pioneer in the study of news values suggesting the existence of certain principles or qualities that are decisive in the selection of news. However, it is actually the seminal work by Galtung and Ruge (1965) that is regarded as the foundational study of these values. Since then, several researchers in the field have proposed various taxonomies, such as Van Dijk (1988), Bell (2001) or O'Neill and Harcup (2009), to mention but a few. Although there is a core of news values that is recognised by most scholars, few investigations have focused on specific news values that may be constructed in the information source.

The present paper presents an investigation of the discourse of news values in the British and Spanish digital media focused on the information source construal. To that end, a brief revision of the different modes of speech representation, as well as the main components present in the citation segment, should first be laid out.

There are two traditional ways of presenting speech that involve semantic differences, namely direct and indirect speech. The former claims to be a verbatim reproduction of a previous statement, whereas indirect speech purports to paraphrase the original utterance. When the speakers/writers paraphrase information, they need to shift all deictic elements and extra-linguistic referents away from direct reference to the speech situation (LEECH; SHORT, 2007, p. 255-256). For instance, (1) "I will pay it next week", Mary told me yesterday vs. (2) Mary told me yesterday that she would pay the electricity bill the following week. In both speech modes, speakers/writers intervene as interpreters of 
the original source of information and the word(s) previously said, thus constructing the evidence in the form of a report.

There are many other stylistic variants of speech representation allowing for greater interference or distance from the quoted information, such as free direct speech or the mixed mode (KUO, 2007; LEECH; SHORT, 2007). The use of a mixed reporting style is very common in the press, where the original speaker's words are embedded, both grammatically and semantically, within the reporter's own discourse (VIS, 2011), as in (3) Mary told me yesterday that she would pay the electricity bill the following week as she was "going through a hard time". This reporting style allows "the maximum effectiveness and vividness in the shortest space possible" (SEMINO, 2009), even distance and responsibility's mitigation from the words of the original speaker.

In the citation or reporting segment, some elements are frequently present. For instance, the source of information ('Mary'), i.e. the original author of the utterance, or the reporting verb ('said'). Sometimes the reporting marker can be a different part of speech, such as an adverb ('allegedly') or a prepositional phrase ('according to'). Other elements can be included in the reporting segment, for instance the addressee of the assertion made by the information source ('me'), or information about the context within which the quoted evidence was provided, for example the date ('yesterday').

Having briefly clarified the main reporting styles and the common elements present in the citation segment, a comprehensive analysis of the sort of news values that are usually construed in the source of information will follow, specifically eliteness and personalisation. These news values configure themselves as the most common options used by journalists when constructing information sources in terms of newsworthiness, as their description is generally positioned towards the elite or the human face of the news actor(s).

\subsection{Eliteness}

The selection of the source of information depends on journalistic judgements of what constitutes news, generally governed by the news value of 'eliteness' (KISUKE, 2004; HJARVARD, 2012). The news selection criteria of eliteness has received distinct terminology in academic research, such as 'prominence', 'eminence', 'importance', 'worth', 'status', 'personalities', 'attribution', 'celebrity' or 'power' (BELL, 2001; MASTERTON, 2005; BRIGHTON; FOY, 2007; MONTGOMERY, 2007, among others). According to Bednarek and Caple (2017), eliteness relates to either human or non-human entities and may incorporate various kinds of 'eliteness' that can be construed in the discourse, such as "status, expertise, authority, celebrity, fame, or stardom" (2017, p. 58). To be more specific, this news value may comprise countries, nations, institutions, organisations, events and happenings of high status, and various kinds of people, such as celebrities, politicians or religious leaders, inter alia (2017, p. 58). The prominence status of the elite is scalar, since it depends on the target audience as well as the basis of its recognition, whether local, national or international (2017, p. 58).

In the case of elite people, they are commonly used as "objects for general identification", preventing ordinary people from the possibility of representing themselves in the news media (GALTUNG; RUGE, 1965, p. 68). Those who are not the elite are normally contacted by the press to supply information based on drama or conflict value; for 
instance, when they are a victim of a crime or a survivor of a disaster (BELL, 2001; KISUKE, 2004; MASTERTON, 2005). As Lampropoulou indicates, the media favours the use of 'official' sources, relegating ordinary people to the presentation of their experiences and reactions to news rather than their opinions (2014, p. 473). Hence, it seems that high status people would legitimate the actions and thoughts of the other segment of society through their (selected) discourse.

One explanation for the prominence of the powerful in the press is the lack of personnel and budgetary constraints, i.e. availability. As a result, journalists are compelled to use institutional rather than private sources of information (ALLERN, 2011, p. 144). According to Gans,

Reporters who have only a short time to gather information must [...] attempt to obtain the most suitable news from the fewest number of sources as quickly and easily as possible, and with the least strain on the organization's budget (1979, p. 128).

Therefore, time constraints and a search of suitability are the causes that might force journalists to resort to the elite. By overusing powerful sources, news reporters emphasise the dissemination of conventional opinions held by the established authority, reinforcing a male-dominated newsroom (CURRAN; SEATON, 2003; MAÑOSOPACHECO, 2018).

Regarding the devices identified in the construction of this news value, Bednarek and Caple acknowledge the following grammatical and lexical resources:

\begin{abstract}
Various status markers, including role labels (Professor Roger Stone, experts); status-indicating adjectives (the prestigious Man Booker prize, top diplomats); recognized names (Hillary Clinton); descriptions of achievement/fame (were selling millions of records a year); use by news actors/sources of specialized/technical terminology, high-status accent or sociolect (esp. in broadcast news) (2017, p. 79, italics in the original).
\end{abstract}

As Mañoso-Pacheco states, all these resources are mainly aimed at portraying the information source as a "competent person based on the idea of authority and prestige" (2017, p. 145). In the case of role labels, there are normally titles or quasi-titles that appear in appositional noun phrases with determiner deletion (e.g. 'Peter Carter, general secretary of the Royal College of Nursing') or in predication (e.g. 'a Palestinian Christian who is a senior official in the Palestine Liberation Organisation'). According to Bell, the construction of apposition with determiner deletion elevates the name of the source to equal status with its description, as if it were a pseudo-title, such as 'President' or 'professor', presenting the news actor as newsworthy (2011, p. 181).

Although sometimes the reporting segment includes the proper name of the sources, these commonly remain anonymous in the description, as in 'experts' or 'officials' (BEDNAREK; CAPLE, 2017, p. 82). Unknown references to sources have been largely discussed in the literature receiving various labels, such as 'mythical groups of reference' or 'unspecified collective sources' (MENZ, 1989; STENVALL, 2008; MAÑOSO-PACHECO, 2017). It is the "aura of secrecy" surrounding the configuration of these sources what makes them construct (and embody) eliteness news value (STENVALL, 2008, p. 233). 
The elite status of sources may also be boosted by means of superlative adjectives in pre-modifying position, such as 'top' or 'prestigious' (BEDNAREK; CAPLE, 2017, p. 82). Moreover, proper nouns referring to entities recognisable to the target audience and occupying a high-status position may also construe eliteness news value (2017, p. 83), for instance, 'Barack Obama'.

As Bednarek and Caple claim, the range of resources that may construct eliteness news value is not a closed list and its elements can be combined. Hence, analysts may encounter many other linguistic devices.

\subsection{Personalisation}

The information source can also construct the news value of 'personalisation'. This newsworthy factor has been treated as synonymous with other terms and expressions such as 'reference to persons', 'personalities', 'familiarity' or 'personification' (GALTUNG; RUGE, 1965; BELL, 2001). According to Bednarek and Caple, this news value is about "giving a 'human' face to the news through references to 'ordinary' people, their emotions, views, and experiences - rather than focusing on abstract issues and processes" (2017, p. 61). Ordinary people are frequently defined as 'non-elite individuals', since they do not act or speak in an official capacity (2017, p. 62). As Galtung and Ruge indicate, "the more the event can be seen in personal terms, as due to the action of specific individuals, the more probable that it will become a news item" (1965, p. 68). However, in the present paper, this news value does not apply to actions performed by individuals in general or quotes coming from them, but the portrayal of personalisation in the reporting segment by showing the human or personal face of the information source.

This news value is quite remarkable in the case of reported speech, where the quoted information needs to be linked to the original source of the assertion, usually a human being, to be presented objectively (HARCUP; O' NEILL, 2001, p. 273). The reason why journalists would prefer constructing the source as an ordinary agent may be due to their attempt to boost readers' identification. Ordinary sources of information easily serve as objects of general identification by means of projection and empathy (GALTUNG; RUGE, 1965, p. 69). Therefore, readers appear to identify more readily when facts are reported by a source of information who is 'like them', rather than elites, even if the quoted facts are processes or abstract issues (BEDNAREK; CAPLE, 2017, p. 90).

The selection of ordinary sources of information facilitates low processing effort of the reported information, in that personalisation value contributes to reduce "complex processes and institutions to the actions of individuals", making stories more comprehensible for the readership (GOLDING; ELLIOTT, 1979, p. 122). In the case of negative news, such as tragedies, the news value of personalisation is commonly shown by emphasising a particular victim. In terms of gender, when portraying negative events writers seem to opt for the female, since women victims appear to be more newsworthy than the male with respect to negative circumstances (AITCHISON, 2006).

In relation to the linguistic resources that may construct the news value of personalisation, Bednarek and Caple indicate the following devices: 
http://periodicos. letras.ufmg.br/index.php/textolivre

Belo Horizonte, v. 13, n. 1, p. 1-19, jan.-abr. 2020 - ISSN 1983-3652

DOI : $10.17851 / 1983-3652.13 .1 .1-19$

References to 'ordinary' people, their emotions, experiences (Charissa Benjamin and her Serbian husband, 'It was pretty bloody scary', But one of his victims sobbed, Deborah said afterwards: 'My sentence has only just begun'); use by news actors/sources of 'everyday' spoken language, accent, sociolect (esp. in broadcast news) (2017, p. 79, italics in the original).

The devices used to construct personalisation contrast with those that construe eliteness, comprising of details about the age, personal description or gender role. These linguistic resources serve to highlight the concreteness of the news actors, as well as to prompt an emotional response from readers (FOWLER, 1994; MAÑOSO-PACHECO, 2017). Within the label of personalisation, vox populi quotes, first names and anaphoric pronouns can also be included as they entail a non-elite label (LEDIN, 1996; BENAARON, 2005; BEDNAREK; CAPLE, 2017).

In the case of reported speech, generally, those sources of information portrayed as ordinary construct the news value of personalisation. Concerning the speech mode, a direct reporting style is usually regarded as more personalising than other speech modes as it allows the audience to access the voice of the individual directly (BEDNAREK; CAPLE, 2017, p. 89). Nevertheless, this study focuses on the configuration of information sources themselves rather than the way in which information is quoted in the discourse.

Finally, it should be noted that the news value of personalisation is both inherent and text-dependent, since the discursive configuration of the source can determine low status. For example, 'real' elite actors can construct personalisation if portrayed as ordinary eye-witnesses involved in an event (BEDNAREK; CAPLE, 2017, p. 90). Thus, the discourse of personalisation news value does not necessarily coincide with the actual prestige of the information source.

\section{Methodology}

The present investigation is corpus-based and analyses contemporary articles published online in 2014 in four broadsheet newspapers in Spain and Great Britain: El Mundo, El País, The Times and The Guardian. The data collection was conducted in 2014 and based on random sampling. It comprises 68 digital articles, both national and international, with an extension ranging from 164 to 1,122 words in length (including headlines and subheadings). The British and Spanish press constitute two corpora that were manually annotated in an Excel database; they have a total number of 20,001 and 20,477 words each, and 519 and 461 reporting segments respectively.

For the sampling purposes, the study is restricted to journalistic texts whose primary concern was to inform readers about a particular event, i.e. articles that do not overtly persuade the readership to perceive events from a particular angle (e.g. editorials). The selected stories feature the topics of Education, Economy and Politics, and to a lesser extent, Sports.

This paper formulates the following research question: what is the discourse of eliteness and personalisation news values in the source of information? The data seeks then to elaborate an inventory of linguistic devices, as well as possible discourse tendencies that construct these newsworthy factors by analysing the source of information. 
In order to analyse eliteness and personalisation, the databases classified sources of information attending to its general characteristics, in particular, animacy value (human vs. inanimate), the type of information source head (e.g. anaphoric allusion, role label, family relationship, etc.) and its modifying elements present in the citation segment, such as place of work, age reference or status-indicating adjectives. Considering the news actor description (both head and modifiers, though the former carries more weight), sources of both corpora were classified attending their resulting news value construal: (mostly) eliteness or (mostly) personalisation. The research also annotated cases of 'weak personalisation' or vox populi, such as 'it is said that', and reporting segments that do not (clearly) construct any of these values, for instance, the impersonal pronoun 'it'.

Although the research establishes four categories depending on the way the information source constructs newsworthiness, only the coding of 'pure' news values has been discussed and compared, i.e. eliteness and personalisation. As was already indicated, these newsworthy categories do not necessarily coincide with the 'real' status of the source, that is, the inherent news value of the agent, but the way the news actor is portrayed in the discourse. Sometimes the very same person may construct the two news values in the discourse, for instance, 'the Ukip leader Nigel Farage' (eliteness) vs. the anaphoric reference 'he' (personalisation). Nevertheless, the configuration of eliteness in the discourse is affected largely by the real-life conditions surrounding the status of the agent, especially in the case of recognised names from politics.

Whilst the research presents a quantitative analysis of eliteness and personalisation, the ambiguity present in the conceptualisation of these newsworthy factors makes it possible to find a certain overlap in the categorisation of some cases. The difficulty when classifying sources arises from the scalar value of these factors and is reflected in the label description 'mostly'. For instance, the elite 'David Cameron' identifies the source using the name of the person, which may be regarded as more personalising than saying 'Mr. Cameron', which in turn can be more personalising than using the role label 'Prime Minister' (BEDNAREK; CAPLE, 2017). Similarly, the indication of the gender of the source may be considered as more personalising than gender-neutral sources, as this feature approaches readers with the human face of the news actor. On the other hand, the ordinary source 'relatives of the four men' that refers to a group of people can be said to be less personalising than the source 'a teenager', which refers to a single individual. Indeed, some authors consider generic or group references as falling under the umbrella of 'weak personalisation' (VAN LEEUWEN, 2008; BEDNAREK; CAPLE, 2017). Nevertheless, for ease of classification this category will be restricted to vox populi cases. Regardless of the scalar nature of these values and the possible errors arising from misattributions of newsworthiness to the information source, the analysis allows for fine distinctions to be drawn more precisely in future investigations concerning the discourse of these values.

\section{Results and discussion}

The quantitative results for the different source categories concerning the news values of eliteness and personalisation in the British and Spanish corpora are shown in table 1 below. Since the number of words in each group of newspapers differs, the results 
are given in both raw numbers $(N)$ and frequency per thousand words $(R)$ in order to normalise the data.

Table 1: Distribution of reporting segments in the British and Spanish corpora as refers the construal of eliteness and personalisation in the information source.

\begin{tabular}{|c|c|c|c|c|c|}
\hline \multirow{3}{*}{ News value } & \multirow{2}{*}{\multicolumn{2}{|c|}{$\begin{array}{l}\text { British press } \\
20,001 \text { words }\end{array}$}} & \multirow{2}{*}{\multicolumn{2}{|c|}{$\begin{array}{c}\text { Spanish press } \\
20,477 \text { words }\end{array}$}} & \multirow{3}{*}{$\mathbf{p}$} \\
\hline & & & & & \\
\hline & $N$ & $\mathrm{R}$ & $\mathrm{N}$ & $\mathrm{R}$ & \\
\hline (Mostly) eliteness & 301 & 15.05 & 226 & 11.04 & 0.0058 \\
\hline (Mostly) personalisation & 115 & 5.75 & 28 & 1.34 & 0.0001 \\
\hline Weak personalisation & 40 & 2.0 & 38 & 1.81 & 0.8134 \\
\hline Unclear / does not apply & 63 & 3.15 & 169 & 7.81 & 0.0001 \\
\hline Total & 519 & 21.45 & 461 & 22.10 & \\
\hline
\end{tabular}

As may be noticed, Table 1 accounts for weak personalisation or vox populi cases. They are hearsay markers (reportative evidentials), which mainly apply to reporting verbs in the passive ('was reported that', 'se especula que' [there is speculation that]), and reportative adverbs and adjectives, such as 'seemingly' or 'presunta' [alleged]. In weak personalisation cases, the quoted evidence seems to come from speculation or common knowledge by an undetermined mass of ordinary people.

Table 1 also indicates the number of reporting segments where there is not a (clear) construct of eliteness and personalisation values. For instance, relative pronouns referring back to an inanimate antecedent ('which', 'that'), the impersonal pronoun 'it', and reporting expressions with implicit sources appearing further back in the text, such as the non-finite verb 'saying'. As in both weak personalisation and unclear cases the source is not coded explicitly, these categories fall outside the scope of the discussion that follows.

In both corpora, sources of information quoted as elites vastly outnumber personalisation configurations, whose distribution is statistically significant $(P<0.05)$ according to the Chi-square test. In fact, in British newspapers there is a ratio of 15.05 in contrast to 5.75 points applied to elites and ordinary sources, respectively. This finding would correlate with Bell's claim, which says that in the press "something is news just because someone elite said it" (2001, p. 193). Therefore, the portrayal of sources as elite seems to be a linguistic device that confers newsworthiness in the media papers analysed in this study.

Table 2 below shows the most common linguistic devices that are found in the elite group of both news groups, i.e., in information sources portrayed in a position of formal authority or with prominent status. 
Table 2: Inventory of linguistic devices that may construct eliteness in the information source.

\begin{tabular}{|c|c|c|c|c|c|c|}
\hline \multirow{2}{*}{$\begin{array}{l}\text { Linguistic } \\
\text { devices }\end{array}$} & \multicolumn{3}{|c|}{ British corpus } & \multicolumn{3}{|c|}{ Spanish corpus } \\
\hline & $\mathbf{N}$ & $\mathbf{R}$ & Examples & $\mathbf{N}$ & $\mathbf{R}$ & Examples \\
\hline Social title & 36 & 1.80 & $\begin{array}{l}\text { Mr, Ms, Sir, } \\
\text { Dr, Dame }\end{array}$ & N/A & 0.00 & \\
\hline $\begin{array}{l}\text { Recognised } \\
\text { names }\end{array}$ & 133 & 6.65 & $\begin{array}{l}\text { Obama, Pope } \\
\text { Francis, } \\
\text { George W. } \\
\text { Bush }\end{array}$ & 84 & 4.10 & $\begin{array}{l}\text { Colau, Patxi } \\
\text { López, Le Pen }\end{array}$ \\
\hline $\begin{array}{l}\text { Role labels } \\
\text { (profession, } \\
\text { rank or field } \\
\text { of expertise) }\end{array}$ & 76 & 3.80 & $\begin{array}{l}\text { Diplomat, } \\
\text { minister, } \\
\text { general } \\
\text { secretary, } \\
\text { governor, } \\
\text { senator }\end{array}$ & 46 & 2.25 & $\begin{array}{l}\text { Juez [judge], } \\
\text { presidente } \\
\text { [president], } \\
\text { eurodiputado } \\
\text { [MEP] }\end{array}$ \\
\hline $\begin{array}{l}\text { Unspecified } \\
\text { (collective) } \\
\text { source }\end{array}$ & 55 & 2.75 & $\begin{array}{l}\text { Officials), } \\
\text { source(s), } \\
\text { leader(s), } \\
\text { expert(s) }\end{array}$ & 25 & 1.22 & $\begin{array}{l}\text { Portavoz } \\
\text { [spokesperson], } \\
\text { analistas } \\
\text { [analysts] }\end{array}$ \\
\hline $\begin{array}{l}\text { Place of } \\
\text { work (name } \\
\text { of the } \\
\text { company, } \\
\text { institution or } \\
\text { organisation) }\end{array}$ & 37 & 1.85 & $\begin{array}{l}\text { The } \\
\text { Palestinian } \\
\text { parliament, } \\
\text { the Royal } \\
\text { College of } \\
\text { Nursing, the } \\
\text { government, } \\
\text { the Bank }\end{array}$ & 44 & 2.15 & $\begin{array}{l}\text { Diputación } \\
\text { [provincial } \\
\text { council], ONU } \\
\text { [UN], Ministerio } \\
\text { de Industria } \\
\text { [Ministry of } \\
\text { Industry] }\end{array}$ \\
\hline $\begin{array}{l}\text { Status- } \\
\text { indicating } \\
\text { modifiers }\end{array}$ & 5 & 0.25 & $\begin{array}{l}\text { Chief, leading, } \\
\text { official }\end{array}$ & 5 & 0.24 & $\begin{array}{l}\text { Oficiales } \\
\text { [official], de } \\
\text { honor } \\
\text { [honoured] }\end{array}$ \\
\hline $\begin{array}{l}\text { Inanimate } \\
\text { sources with } \\
\text { broad scope }\end{array}$ & 78 & 3.90 & $\begin{array}{l}\text { Britain, Tel } \\
\text { Aviv, China, } \\
\text { US, Beijing, } \\
\text { FBI, } \\
\text { government, } \\
\text { Bank, } \\
\text { Washington } \\
\text { Post, police }\end{array}$ & 93 & 4.54 & $\begin{array}{l}\text { Bruselas } \\
\text { [Brussels], } \\
\text { Moscú } \\
\text { [Moscow] Casa } \\
\text { Blanca [White } \\
\text { House], } \\
\text { Comisión } \\
\text { Europea } \\
\text { [European } \\
\text { Comission] }\end{array}$ \\
\hline
\end{tabular}

In general, the construal of elites is more inherent, cultural and time-bound than 
personalisation news value. This fact may be reflected in the use of recognised names with prestige, such as 'David Cameron' or 'Le Pen', a device that is much frequent in the British corpus. Most of these sources come from political positions and depending on the cultural background of the scholar and the time they examine them, the set level of status might vary. Hence, the socio-cultural background of the researcher and the time frame of the study can affect the results concerning this linguistic resource.

There are examples in the two corpora of role label configuration, such as 'the Prime minister' or 'the governor'. Being a socially validated authority seems to be a prerequisite to give credit for the reported information, which is reflected discursively via the indication of the place of work. For instance, 'el experto en riesgos naturales y vocal del Colegio de Geógrafos de España Jonathan Gómez Cantero' [the expert on natural hazards and member of the Association of Geographers of Spain Jonathan Gómez Cantero] vs. 'A teenager who disappeared in California 10 years ago', the latter being an unaffiliated individual.

The elite status of sources is also reinforced by the use of capital letters ('Minister' instead of 'minister'), as well as pre-modifiers that allude to their rank or field of expertise, as in 'el vicepresidente Florian Philipott' [the vice president Florian Philipott]. Besides, the high position of the elite is enhanced by means of status-indicating adjectives ('chief', 'leading') and apposition nominal groups indicating the profession of the source, for instance, 'Boris Johnson, the London mayor'.

In the case of the British corpus, personal titles, such as 'Mr', 'Dame' or 'Ms', are used to strengthen the prominent role of the information source. In Spanish newspapers, on their part, there is a presence of ordinary people shaped as elite sources by means of their affiliations to associations, organisations or institutions that defend their interests, as in 'la Plataforma Víctimas Alvia 04155' [the Alvia 04155 Victims Platform].

In both corpora there are found a few 'unknown' elites, in the sense that the exact identity of the sources remains unidentified for the readership, for example 'officials', 'analysts', 'authorities' or 'sources', to name but a few. Nevertheless, this linguistic device is slightly more common in the British press, with a difference of 1.53 points in the ratio per thousand words in comparison with the Spanish corpus.

Eliteness is not just restricted to human sources, a few metonymic expressions denoting inanimate entities that enhance this newsworthy value are also found in the two corpora. For example, 'el ministerio' [the ministry] or the acronym 'SNCF' (French National Railway Company), which denote the institutions where powerful sources work. As regards the discourse of inanimate elites, mostly having a broad scope, the use of status-indicating adjectives is frequent in the British press, such as 'central' or 'official', as well as genitive constructions, for example, 'the Bank of England' or 'the government's Health and Social Care Information Centre'. The use of non-human elites to construct eliteness value is a recurrent linguistic resource in both news groups, having a distribution of 3.90 and 4.54 ratio of tokens in the British and Spanish corpus, respectively.

The comparison between the Spanish and the British corpora as regards personalisation news value is also statistically significant $(P<0.05)$ according to the Chisquare test, as was already indicated in table 1. Although British sources may seem to construct personalisation to a larger extent, the difference in the ratio in the two news groups has to do with the properties of the language. In English, the subject must normally appear in the phrase, whereas in Spanish its explicit coding is not mandatory. Indeed, 
British newspapers construct many ordinary sources by means of anaphoric allusions, such as personal pronouns.

Focusing on the discourse of this news value, Table 3 below indicates the variety of linguistic devices that may construct this newsworthy factor.

Table 3: Inventory of linguistic devices that may construct personalisation in the information source.

\begin{tabular}{|c|c|c|c|c|c|c|}
\hline \multirow{2}{*}{$\begin{array}{l}\text { Linguistic } \\
\text { devices }\end{array}$} & \multicolumn{3}{|c|}{ British corpus } & \multicolumn{3}{|c|}{ Spanish corpus } \\
\hline & $\mathbf{N}$ & $\mathbf{R}$ & Examples & $\mathbf{N}$ & $\mathbf{R}$ & Examples \\
\hline $\begin{array}{l}\text { Anaphoric } \\
\text { allusions }\end{array}$ & 85 & 4.25 & $\begin{array}{l}\text { Her, he, I, } \\
\text { she, they, } \\
\text { who }\end{array}$ & 6 & 0.29 & $\begin{array}{l}\text { Su [her/his], } \\
\text { quien [who] }\end{array}$ \\
\hline $\begin{array}{l}\text { Family or } \\
\text { personal } \\
\text { relationship }\end{array}$ & 4 & 0.20 & $\begin{array}{l}\text { Relatives, } \\
\text { mother, } \\
\text { son-in-law, } \\
\text { friend }\end{array}$ & 9 & 0.44 & $\begin{array}{l}\text { Madre } \\
\text { [mother], } \\
\text { padre [father], } \\
\text { tío [uncle], } \\
\text { familias } \\
\text { [families], } \\
\text { hermano } \\
\text { [brother] }\end{array}$ \\
\hline $\begin{array}{l}\text { Marital } \\
\text { status }\end{array}$ & N/A & 0.00 & & 2 & 0.10 & $\begin{array}{l}\text { Exesposa [ex- } \\
\text { wife], } \\
\text { compañero } \\
\text { sentimental } \\
\text { [intimate } \\
\text { partner] }\end{array}$ \\
\hline $\begin{array}{l}\text { Personal } \\
\text { reference }\end{array}$ & 1 & 0.05 & Men & 2 & 0.10 & $\begin{array}{l}\text { Hombre } \\
\text { [man], } \\
\text { personas } \\
\text { [people] }\end{array}$ \\
\hline $\begin{array}{l}\text { Age } \\
\text { reference }\end{array}$ & 2 & 0.10 & $\begin{array}{l}\text { Most } \\
\text { senior, } \\
\text { teenager }\end{array}$ & 4 & 0.20 & $\begin{array}{l}\text { Jóvenes } \\
\text { [youngsters], } \\
46 \text { (years), } \\
1974 \text { (year of } \\
\text { birth) }\end{array}$ \\
\hline $\begin{array}{l}\text { Place of } \\
\text { origin } \\
\text { (applied to } \\
\text { individuals) }\end{array}$ & 15 & 0.75 & $\begin{array}{l}\text { Finnish, } \\
\text { European, } \\
\text { Swedish, } \\
\text { British, } \\
\text { French, } \\
\text { Iranian }\end{array}$ & 28 & 1.37 & $\begin{array}{l}\text { Vasco } \\
\text { [Basque], } \\
\text { sevillano } \\
\text { [Sevillian], de } \\
\text { Huelva [from } \\
\text { Huelva], } \\
\text { nacida en } \\
\text { Barcelona } \\
\text { [born in }\end{array}$ \\
\hline
\end{tabular}




\begin{tabular}{l|l|l|l|l|l} 
& & & & Barcelona] \\
Negativity \\
reference
\end{tabular}

Some of the most common linguistic resources that apply to personalisation construal in the British corpus are possessive determiners belonging to the source description ('her'), relative pronouns in subject position referring back to people ('who'), and anaphoric pronouns in subject position ('l', 'he'). In the Spanish news group there are a few adverbial phrases initiating the citation segment that influence the configuration of the source that follows by enhancing her/his personal face, for instance, 'en su opinión', 'a su juicio' [in his/her opinion].

Other linguistic devices to construct personalisation that appear in both corpora comprehend personal or family relationships ('hermano del reportero australiano' [the brother of the Australian reporter]) and nationality or place of origin ('la activista, nacida en Barcelona en 1974' [the activist, born in 1974 in Barcelona]), a resource which also collocates with elite heads, as in 'the Finnish premier'. The indication of provenance applied to individuals is more prominent in the British corpus, exhibiting a ratio of 1.37 per thousand words. There are a few other minor linguistic devices found that humanise sources in the two news groups, such as the age of the news agent ('most senior') and references to marital status ('su exesposa, Laura Muñoz' [his ex-wife, Laura Muñoz]), the latter only present in Spanish newspapers.

The researcher must clarify that the indication of the place of origin by itself is not a feasible indicator of personalisation construction, since there are, for instance, compound adjectives ('California-based'), pre-modifying nouns ('London') and compound nouns acting as pre-modifiers that tend to collocate with elite heads, for instance, 'Santa Ana police'. Likewise, it should be noted that the use of first names in head position, a device not applied to any corpora, does not always construct personalisation; for instance, if preceded by a role label, as in papal names. Although early popes retained their birth names, nowadays they adopt a new name upon their accession that does not coincide with their baptismal name. Thus, the source 'Pope Francis', which is found in the British 
corpus, has been regarded in the study as an elite compound designation.

The linguistic devices that construct personalisation are commonly found in long chains of words in post-head position, clarifying the identity of the agent from a human angle, as in this apposition embedding a restrictive relative clause 'Nicola Evans, a friend of Bridge who started the petition,'. Since ordinary sources are normally unknown for the general public, there is a greater need than in elites to provide with further details in the source description. These resources are also often part of Saxon genitive construction, especially when referring to family relationships, as in 'Mr Warren's son-in-law'.

Finally, there are a few instances of negativity news value as a construal of personalisation. The discourse configuration of ordinary folks by means of linguistic devices of negativity can be exemplified in the information source 'algunos testigos que presenciaron el accidente' [some witnesses who witnessed the accident]. This fact would support the claim that the media frequently contact ordinary people to supply information when they witness a negative event, such as a crime, a disaster or an accident. However, this fact would require further investigation considering the reduced number of instances found in the two corpora.

\section{Conclusions}

The present investigation has reviewed the discourse of news values in the source of information. Based on previous studies in the field of critical discourse analysis (VAN DIJK, 1988; BELL, 2001; BEDNAREK; CAPLE, 2017, amongst others), this research has centred its study on eliteness and personalisation, in particular, the linguistic devices used in the construal of these news factors in the source description.

Considering the results derived from the analysis, the researcher may conclude that when dealing with sources of information, as one might expect, there seems to be a greater approval for the use of elites playing the role of experts as a distinctive newsworthy value in digital journalism. The identity of these sources sometimes remains unknown for the readership, as in 'officials', 'experts' or 'analysts', enhancing their status.

As regards the discourse of eliteness, this news value was mostly characterised by the presence of recognised names from politics ('Barack Obama', 'Le Pen'), especially in British newspapers, and the use of inanimate references with broad scope, such as 'the government' or 'Britain'. In the two corpora it was also common to see the use of role labels that indicate the profession or field of expertise of the source ('the mayor', 'the judge'), generally appearing in apposition. Besides, status-indicating modifiers were used to reinforce the position of news actors ('leading', 'official'), though this was not so frequently observed in the news groups. Finally, the use of personal titles, such as 'Mr' or 'Dame', was a recurrent linguistic device found in British newspapers in order to enhance the elite position of the information source.

In the case of personalisation, this newsworthy factor was mostly constructed in the British corpus by means of anaphoric allusions, namely relative pronouns, pronouns in subject position and possessive determiners. The linguistic devices to construct personalisation also comprised reference to marital status, age details and family relationships, the latter frequently embedded in Saxon genitive and appositional constructions. Moreover, the indication of provenance or place of origin was a recurrent 
linguistic device in the British corpus. In line with previous research, the news value of negativity seems to marginally construct ordinary folks. However, this research paradigm requires more in-depth examination as the number of instances constructing these news values is reduced in both corpora.

The study would suggest further research with respect to the extra-journalist and organisational selection decisions taken in the editorial conferences. Extensive investigation would also be needed regarding the compatibility of the information source with the newspaper's bias, the so-called 'consonance' news value. The researcher has not yet reached the various ideological lines supposedly held in society and mirrored by the digital press, and so an all-encompassing analysis that may help readers better direct their information processing would be desirable as a vibrant continuation of this investigation.

\section{References}

AITCHISON, J. Headlines and deadlines: changing newspaper language. Plenary lecture given at the Atti del XII Congresso Internazionale di Lessicografia, Torino, 6-9 September 2006.

ALLERN, S. Journalistic and commercial news values news organizations as patrons of an institution and market actors. Nordicom Review, v. 23, n. 1, p. 137-152, 2011.

BEDNAREK, M. Voices and values in the news: News media talk, news values and attribution. Discourse, Context and Media, v. 11, p. 27-37, 2016.

BEDNAREK, M., CAPLE, H. The Discourse of News Values. New York: OUP, 2017.

BELL, A. The Language of News Media. Oxford: Basil Blackwell, 2001.

BELL, A. Leaving home: De-Europeanisation in a post-colonial variety of broadcast news language. In: KRISTIANSEN, T.; COUPLAND, N. (ed.). Standard Languages and Language Standards in a Changing Europe. Oslo: Novus, 2011. p. 177-198.

BEN-AARON, D. Given and news: Evaluation in newspaper stories about national anniversaries. Text, v. 25, n. 5, p. 691-718, 2005.

BLANCO-GÓMEZ, M. Encoding writer's attitudinal stance. In: MARÍN-ARRESE, J. (ed.). Perspectives on Evidentiality and Modality. Madrid: Editorial Complutense, 2004. p. 245266.

BOYD, A. Broadcast Journalism Techniques of Radio and Television News. Oxford: Focal Press, 2001.

BRIGHTON, P.; FOY, D. News Values. London: Sage, 2007.

CAPLE, H. News Values and Newsworthiness. In: ORNEBRING, H. (ed.). Oxford 
Research Encyclopedia of Communication. Oxford: Oxford University Press, 2018.

COTTER, C. News Talk. Investigating the Language of Journalism. Cambridge: Cambridge University Press, 2010.

CURRAN, J.; SEATON, J. Power without Responsibility: The Press, Broadcasting, and New Media in Britain. London: Routledge, 2003.

DE NIES, T.; D'HEER, E.; COPPENS, S.; VAN DEURSEN, D.; MANNENS, E.; PAULUSSEN, S.; VAN DE WALLE, R. Bringing newsworthiness into the 21st century. Web of Linked Entities Workshop (WoLE), p. 106-117, 2012.

FOWLER, R. Language in the News: Discourse and Ideology in the Press. London and New York: Routledge, 1994.

GALTUNG, J.; RUGE, M. H. The structure of foreign news. Journal of Peace Research, v. 2, n. 1, p. 64-91, 1965.

GANS, H. Deciding What's News: A Study of "CBS Evening News," "NBC Nightly News," Newsweek, and Time. New York: Pantheon, 1979.

GOLDING, P., ELLIOT, P. Making the News. London: Longman, 1979.

GUO, Q. Perceptions of news value: comparative research between China and the United States. China Media Research, v. 8, n. 2, p. 26-35, [1979] 2012.

HARCUP, T.; O'NEILL, D. What Is News? Galtung and Ruge revisited. Journalism Studies, v. 2, n. 2, p. 261-280, 2001.

HARRISON, J. News. London: Routledge, 2006.

HJARVARD, S. The study of news production. In: JENSEN, K. (ed.). A Handbook of media and communication research: qualitative and quantitative methodologies. London and New York: Routledge, 2012. p. 87-105.

KISUKE, C. An investigation of the role of news values in the selection of news sources in a contemporary third world newspaper: a case study of the Daily Nation. 2004. MA thesis, Rhodes University, 2004.

KUO, S. Language and ideology: analyzing quotations in Taiwanese news discourse. Journal of Asian Pacific Communications, v. 17, n. 2, p. 281-301, 2007.

LAMPROPOULOU, S. Greece will decide the future of Europe: The recontextualisation of the Greek national elections in a British broadsheet newspaper. Discourse \& Society, v. 25, p. 467-482, 2014.

LEDIN, P. The prime minister, Ingvar Carlsson, he or Ingvar? Anaphoric expressions in 
newspaper discourse. Nordic Journal of Linguistics, v. 19, n. 1, p. 55-80, 1996.

LEECH, G.; SHORT, M. Style in Fiction: A Linguistic Introduction to English Fictional Prose. Edinburgh: Pearson, 2007.

LIPPMANN, W. Public Opinion. New York: The Free Press, 1922.

LOZADA, C. 200 journalism cliches - and counting. Washington Post, 2014. Available at https://www.washingtonpost.com/news/opinions/wp/2014/02/27/the-outlook-list-of-thingswe-do-not-say/?noredirect=on\&utm term=.84719f85005e. Accessed on: 2 November 2017.

MAÑOSO-PACHECO, L. Reporting the Source of Information in the British and Spanish Press: A Taxonomy of Expressions. In: CARRETERO, M.; DOMÍNGUEZ, E.; LAVIDLÓPEZ, J.; MARTÍN DE LA ROSA, M. V.; MARÍN-ARRESE, J.; PÉREZ, M. (ed.). Evidentiality and Modality in European Languages. Bern, Switzerland: Peter Lang, 2017, p. 139-168.

MAÑOSO-PACHECO, L. Gender asymmetries in news reports. Miscelánea: A Journal of English and American Studies, v. 57, p. 121-139, 2018.

MASTERTON, M. Asian journalists seek values worth preserving. Asia Pacific Media Educator, v. 16, n. 6, p. 41-48, 2005.

MENZ, F. Manipulation strategies in newspapers: A program for critical linguistics. In: WODAK, R. (ed.). Language, Power and Ideology: Studies in Political Discourse. Amsterdam: John Benjamins, 1989. p. 227-249.

MONTGOMERY, M. The Discourse of Broadcast News. A Linguistic Approach. London and New York: Routledge, 2007.

O'NEILL, D.; HARCUP, T. News values and selectivity. In: WAHL-JORGENSEN, K.; HANITZSC, T. (ed.). The Handbook of Journalism Studies. New York and London: Routledge, 2009. p. 161-174.

RANDALL, D. The Universal Journalist. London: Pluto, 2000.

REAH, D. The Language of Newspapers. London and New York: Routledge, 2001.

RICHARDSON, J. Analysing Newspapers. An Approach from Critical Discourse Analysis. Basingstoke: Palgrave Macmillan, 2007.

SEMINO, E. Language in newspapers. In: CULPEPER, J.; KATAMBA, F.; KERSWILL, P.; WODAK, R.; MCENERY, T. (ed.). English Language: Description, Variation and Context. London: Palgrave Macmillan, 2009. p. 439-453.

SERGEANT, J. Give me Ten Seconds. London: Macmillan, 2001. 
SHOEMAKER, P. News and newsworthiness: A commentary. Communications, v. 31, n. 1, p. 105-111, 2006.

STAAB, J. The role of news factors in news selection: A theoretical reconsideration. European Journal of Communication, v. 5, p. 423-443, 1990.

STENVALL, M. Unnamed sources as rhetorical constructs in news agency reports. Journalism Studies, v. 9, n. 2, p. 229-243, 2008.

VAN DIJK, T. News as Discourse. Hillsdale and New Jersey: Lawrence Erlbaum Associates, 1988.

VAN LEEUWEN, T. J. Discourse and Practice - New Tools for Critical Discourse Analysis. New York: Oxford University Press, 2008.

VIS, K. Subjectivity in news discourse: A corpus linguistic analysis of informalization. 2011. PhD dissertation, Vrije Universiteit Amsterdam, 2011.

Recebido em dia 27 de outubro de 2019. Aprovado em dia 28 de dezembro de 2019. 